\title{
Why Black and Brown Youth Fear and Distrust Police: An Exploration of Youth Killed by Police in the US (2016/2017), Implications for Counselors and Service Providers
}

\author{
Rafael Outland \\ Department of Counselor Education at the College at Brockport, State University of New York (SUNY), Brockport, \\ New York, USA \\ Email: routland@brockport.edu
}

How to cite this paper: Outland, R. (2021). Why Black and Brown Youth Fear and Distrust Police: An Exploration of Youth Killed by Police in the US (2016/2017), Implications for Counselors and Service Providers. Open Journal of Social Sciences, 9, 222-240.

https://doi.org/10.4236/jss.2021.94017

Received: March 18, 2021

Accepted: April 19, 2021

Published: April 22, 2021

Copyright $\odot 2021$ by author(s) and Scientific Research Publishing Inc. This work is licensed under the Creative Commons Attribution International License (CC BY 4.0).

http://creativecommons.org/licenses/by/4.0/ Open Access

\begin{abstract}
Black and Brown youth homicides by police remain a public health epidemic. Such occurrences can contribute to these youth's fear and distrust toward officers. The purpose of this manuscript was to provide evidence of why Black and Brown youth fear and distrust police, and to discuss implications for counselors and service providers who work with survivors of youth killings by police. Using a preexisting database, this work explored the frequency of youth killings by police in $2016 / 2017$. Descriptive statistics were used for data analysis. Results revealed that 116 youth were killed by police. Black males were killed four times more often than Brown and White males, and White females were killed four times more often than Black females. Recommendations for government and judicial services, along with youth activists and mental health care providers, are discussed.
\end{abstract}

\section{Keywords}

Children and Teens, Extrajudicial-Killings, Race and Gender, Police Accountability, Mental Health, Counseling Implications

\section{Introduction}

Young people in the United States of America (US), especially Black and Brown teens, possess high levels of distrust and fear toward law enforcement. According to data from the Surveillance for Violent Deaths National Violent Death Reporting System, police killings were the third leading cause of violence-related 
deaths in 2014 , accounting for $24.4 \%$ of the more than 16,000 violent-related deaths in 16 states. In this count, Black males were 21 times more likely to be killed by police than White males (Gilbert \& Ray, 2015: p. 123). In addition, the Malcolm X Grassroots Movement discovered that in 2021, police killed more than 313 Black people-one every 28 hours (Shane, Lawton, \& Swenson, 2017). Furthermore, some studies found that Black teens hold fear and distrust toward police due to witnessing their Black and Brown peers in the media being harassed, beaten, or lose their lives to police with impunity (Staggers-Hakim, 2016). Such fear and distrust can also stem from the impact of police killings on the family, friends, and loved ones of youth victims. These traumatic events can lead to complex grief and traumatic stress, which can involve ruminating thoughts of the event, challenges with daily activities, long-term mental and emotional struggles, and continued encounters and harassment by police (Outland, Noel, Rounsville, Boatwright, Abraham, \& Waleed, 2020).

Although several cases of youth killings by police have received public attention in recent years, including the untimely murder of Michael Brown by Ferguson officer, Tamir Rice by Ohio officer, Paul O’ Neal Jr. by Chicago officer, and Jordan Edwards by Balch Springs officer (Hill, 2016), the majority cases of youth killed by police remain unnoticed and under-researched (Chaney \& Robertson, 2013; Miller, 2015). Thus, the distrust and fear held by Black and Brown youth toward police seem justified upon first review of the above-mentioned cases. Moreover, the number of youth who lose their lives to police violence remain undercounted and unrecognized (Shane, Lawton, \& Swenson, 2017). This article provides empirical evidence for counselors and service providers to better understand why Black and Brown youth fear and distrust police. This evidence includes a comprehensive calculation of the frequency of youth killed by police in the US between January 2016 and August 2017, and police accountability following the events. Becoming aware of this information can assist counselors and service providers in 1) understanding the social, emotional, and mental health consequences on Black and Brown youth, and 2) developing culturally relevant interventions, social justice or counseling, to support survivors of these traumatizing events.

\section{Extrajudicial Killings of Citizens by Police}

Extrajudicial killings of citizens by police remains a public health epidemic in the US (Johnson, Hoyer, \& Heath, 2014; Belur, 2010). Extrajudicial killings can be defined as the killing of a person by police without the sanction of any judicial proceeding or legal process, or with impunity (US Legal, 2017; Gilbert \& Ray, 2015). For example, between 2013 and 2016, 4289 citizens were killed by police and law enforcement agents in the US, an average of 1072 lives per year (Killedbypolice, 2021). In almost all cases involving police killings, it is rare or never that an officer is convicted of murder, or a crime (Gilbert \& Ray, 2015; Belur, 2010). Furthermore, according to Phillip Stinson, Associate Professor in Criminology at Ohio's Bowling Green State University, zero officers were convicted of 
murder in 2014 and 2015. He further suggested that only 13 officers have been convicted of murder or manslaughter since 2005 (Ferner \& Wing, 2016). In light of Black and Brown youth's fear and distrust toward police, the above-mentioned information is important to consider for two reasons. First, most officers responsible for the killing of a youth with impunity (i.e. justified homicide), return to active duty in the neighborhood where the police homicide took place (Belur, 2010). In other words, the family and friends of the victim must experience the daily presence of the officer who killed their loved one in the aftermath of this tragic event. Furthermore, due to the officer's return to active duty, he is granted state authority to continue to patrol the community of the deceased victim. These realities in the aftermath of a police killing of a citizen further exacerbate Black and Brown youth's fear and distrust toward police due to increased possibilities of racial profiling and harassment by officers (Aymer, 2016; Outland et al., 2020; Smith, 2015). Moreover, these realities can have an adverse influence on the psychological and emotional wellbeing of the victim's family and friends (Rheingold et al., 2012; Zinzow et al., 2009; Staggers-Hakim, 2016). Counselors and service providers must be aware of the above-mentioned realities of survivors of youth killings by police, in order to identify appropriate counseling and advocacy interventions to help those impacted to heal and receive justice following the untimely death of their loved one (Kristensen, Weisaeth, \& Heir, 2012; Weitzer \& Brunson, 2009).

Extrajudicial killings of youth by police. Although recent scholars, activists, and concerned citizens have archived extrajudicial killings of citizens by police or law enforcement officers in the US, youth killed by police remain under researched (Strohlic, 2014; Cohen, 2017; Craven, 2017; Staggers-Hakim, 2016). Specifically, in a 2014 article released by the Daily Beast titled "The 14 Teens Killed by Cops since Michael Brown," Nina Strohlic provided vague, yet important, information regarding Black teen males who were killed by law enforcement agents. Such information included the victims' names, ages, and circumstances that led to the police killing. Although these facts are relevant to understand the predatory nature of police when acting as judge and jury toward Black male youth (Gilbert \& Ray, 2015), this article failed to identify and discuss the killings of Black female and non-Black youth. Moreover, although it is vital to recognize that Black teen males were 4.5 times more likely to be killed by police than any other ethnic group during this period (Strohlic, 2014; Shane et al., 2017), this information does not disclose the number of Brown and White youth killed by police. Specifically, Gilbert and Ray (2015) acknowledge the sociohistorical context of systemic racism toward Blacks and poor people in the US. They suggest that Black people have historically remained primary target of state sanction violence by police, or death by lethal intervention, as a result of laws and judicial mandates that allow officers to kill with impunity. In addition, the researchers acknowledge the role of the media in shaping public opinion about circumstances that led to victims' fatal encounters with police, in which the me- 
dia criminalizes the victim long before details from the investigation are released to the public (Gilbert \& Ray, 2015). Thus, we can assume that the lack of public discourse surrounding the untimely death of majority Black, Brown, and White youth by police is a result of sociohistorical systemic racism in the US that has continued to criminalize victims of state sanctioned violence by officers, and found their actions to be justified over time.

In January 2017, the Huffington Post released an article titled "More than 250 Black people were killed by police in 2016 [UPDATED]." According to Julia Craven (2017), "Black males between ages 15 and 34 were nine times more likely to be killed by police than their racial counterparts...even though Black males in this age range make up $2 \%$ of the general population" (para. 14). Although this information is important to acknowledge, it does not take into consideration the specific number of Black, and Brown, and White youth killed by police during this period. Moreover, this article does not take into account the other $85 \%$ of victims of extrajudicial killings by police or law enforcement.

\section{Impact of Violent Death on Homicide Survivors}

Limited research has been conducted surrounding the impact of police killings on the lives of children, teens, and adults (Outland et al., 2020). However, some studies have investigated the impact of traumatic death on the lives of teen and adult homicide survivors. For example, research found that the homicide of a loved one or friend can lead to experiences of depression, PTSD symptoms, and emotional instability for adolescents and adults (Rheingold, Zinzow, Hawkins, Saunders, \& Kilpatrick, 2012; Zinzow, Rheingold, Hawkins, Saunders, \& Kilpatrick, 2009). In addition, research discovered that the family and loved ones of homicide survivors, especially related to violent deaths, are more likely to experience the above-mentioned symptoms, due to their ongoing involvement with the judicial system and court cases related to the death of their loved one (Kristensen et al., 2012; Nakajima, Ito, Shirai, \& Konishi, 2012). Finally, the emotional and psychological challenges experienced by most homicide survivors are not short-lived, but carry the potential to impact their long-term emotional, psychological, and physical development (Rheingold et al., 2012; Nakajima et al., 2012).

Counselors and service providers who work with children and teenagers, especially Black and Brown youth, have a professional obligation to ensure the safety of young people at school and home (Counseling.org, 2019; ACA, 2014; Lopez-Baez \& Paylo, 2009). Because many Black and Brown youth tend to distrust and fear the police (Staggers-Hakim, 2016), counselors and service providers are in prime positions to advocate for change in local, state, and national policy that hold police accountable for their actions in the line of duty. In other words, these youth advocates can act as change agents to transform policies that aim to increase police accountability in the aftermath of youth killings by police. If officers are not held accountable by the laws and courts when taking the life of a youth, then chances are that Black and Brown young people 
will maintain positions of distrust, fear, resentment, and possibly hate, toward the forces who are paid by US tax dollars to protect them (Chaney \& Robertson, 2013; Hill, 2016).

\section{Killedbypolice.net}

Killedbypolice.net, is a public domain that has tracked and archived police killings of citizens in the US from 2013 to 2021 (Killedbypolice, 2021). The website provides detailed information about the victims, including their names, ages, city and state, picture, and a web link for readers to google search to review a news article about the event. The website reported that since 2013, at least 4289 citizens have been killed by police, and 1065 and 1089 people were killed in 2016 and 2017, respectively. More importantly, this database acknowledges the children and teenagers killed by police in the US, whereas some public databases tracking citizens killed by police have omitted this vital information. In order to identify and acknowledge the impact of extrajudicial killings of citizens by police in the US (Gilbert \& Ray, 2015; Shane et al., 2017; Staggers-Hakim, 2016), it is important to take into account the frequency of children and teens who lost their lives to this epidemic. An initial examination could include the number of youth (E.g. children and teens) killed by police, as well as officers' accountability in the aftermath of these traumatic events.

Thus, in an attempt to provide evidence related to Black and Brown young people's fear and distrust toward police, this article calculated the frequency of all youth killed by law enforcement officers between January 2016 and August 2017. The purpose of this manuscript was twofold: 1) To provide empirical evidence related to Black and Brown youth's fear and distrust toward police, and 2) To discuss implications for counselors and service providers when working with and advocating for survivors of youth killed by police. Using a publicly accessible domain (killedbypolice.net) as the site for participant recruitment, a total of 116 youth victims were included in the study. In addition, the aim of the study was to address the following research questions:

How many children and teenagers ( 0 - 19 years-old) have been killed by police or law enforcement agents since 2016 ?

What were the outcomes and accountability to police and law enforcement agents in the aftermath of these occurrences?

Finally, the overall aim of this work is to assist counselors and service providers in understanding some of the primary contributors of Black and Brown youth distrust and fear toward police. By understanding these contributors, counselors and service providers can work with schools, communities, and local governing officials to advocate for systemic change, with hopes of holding police accountable in the aftermath of a youth death by police (Gilbert \& Ray, 2015). In addition, such an understanding may assist counselors in determining appropriate remedies to assist the family and friends in healing and coping with the social, mental, and emotional wounds of losing their loved one (Rheingold et al., 2012; Weitzer \& Brunson, 2009). The following section discusses the methodol- 
ogy used in the study.

\section{Method}

\section{Participants}

All participants were sampled from a preexisting database known as Killedbypolice (Killedbypolice, 2016). Killedbypolice database consisted of all victims of police and law enforcement extrajudicial killings in the US from 2013 to July 2018. As a result, this study accounted for specifically children and teenagers who were killed by police from January 1, 2016 to August, $31^{\text {st }}$, 2017. This timeframe was determined based on the time when the original research took place (i.e. Data collection occurred in summer 2017). Inclusion criteria for participants in the study was the following:

1) Killed by police or law enforcement officer(s) from January 1, 2016 to August, $31^{\text {st }}, 2017$

2) Ages 0 to 19 years old

Participant exclusion criteria for this work included victims of police killings who were age 20 or older. It should be noted that all adult victims of police killings lives matter and are deserving of fair investigations and justice. However, due to the rarity in existence of a database for youth victims of police killings, the author believed it necessary to create one for the purpose of this project. Thus, $116(\mathrm{~N}=116)$ youth victims were included in this investigation. In regards to gender, a total of 108 males $(\mathrm{N}, \mathrm{M}=108)$ and eight females $(\mathrm{N}, \mathrm{F}=8)$ were sampled. According to race, a total of 54 Blacks, 24 Latino, and 24 White youth were sampled. Finally, 14 youth in were identified in the racial category of $O$ ther (E.g. Indigenous, Alaskan, Asian, Middle Eastern, and Pacific Islander; See Appendix II for further details).

\section{Procedures}

This study was not submitted to the Institutional Review Board (IRB) for approval because the preexisting database for participant recruitment is a public domain (Killedbypolice, 2021). The author facilitated and completed the process of data collection and analysis. Specifically, data in this study were collected over an eight-week period in several steps. Week one consisted of determining that the database Killedbypolice.net was an appropriate one for this study for three primary reasons. First, the database tracked victims of extrajudicial killings by police and law enforcement from 2013 to summer 2021. Second, the database archived the victim's name, age, race, and location of youth homicides by police, and provided a picture of most victims. Third, the database provided a web address or link for viewers to read an original article about the occurrence (Killedbypolice, 2021).

Week two through four consisted of participant selection process for the study. As previously mentioned, victims ages 0 to 19 who were killed by police or law enforcement officers were sampled for this study. A total of $\mathrm{N}=116$ children and teenagers were sampled. Week five and six consisted of categoriz- 
ing participant information on an Excel spreadsheet and a word document. Categorical data included participants' name, age, race, location, circumstances, outcomes, police accountability/consequences, and web link. Categorical data on the word document were less detailed, which included participants' name, age, race, location, picture, and the department of the agent involved in the youth homicide (e.g. Killed by New York Police officers). The final excel database and word document of participant information were stored on the author's password secured computer hard-drive, and backed up on a password-encrypted external hard-drive. Because all information of participants were available on public domains (e.g. news outlets and reports), maintaining confidentiality of participants was not a concern in this study. Moreover, participants' names were not included in this manuscript. There were no associated risks or benefits for participants in this work, being that they are deceased youth victims of police killings. Finally, week eight consisted of the data analysis process, which is denoted in more detail below. Following the data analysis process, the final results were graphed according to the above-mentioned categories. (Note: All graphs of results can be found in the appendix section of paper)

\section{Data Analysis}

Descriptive statistics were used for data analysis in this study. Specifically, the mean, median, mode, and standard deviation were calculated according to the age of victims. Furthermore, total averages were calculated based on gender and race of victims. These calculations produced statistical outcomes for the results. All results from calculations were stratified according to the year of the occurrence (E.g. Jan. 1, 2016 to Dec. 31, 2016; Jan. 1, 2017 to Aug. 31 ${ }^{\text {st }}$ 2017). Finally, it must be noted that further statistical calculations could be produced for the current database according to the researcher's purpose and goal for the study. Since the focus of this study was to calculate the frequency of youth victims of police killings during a given time as well as police accountability following these events, the utility of basic statistics were used to produce the results in this research, which are denoted in the following sections.

\section{Results}

This study investigated the number of children and teenagers killed by police between January 2016 and August 2017. Using a preexisting database known as killedbypolice.net (Killedbypolice, 2016), this study explored categorical data of youth victims killed by police, including their names, age, race, location, outcomes, and web links for the occurrence. Data collected for each victim was organized using an excel spreadsheet, and descriptive statistics were used to explore several categories, which are presented below.

\section{Children and Teenagers Killed by Police and Law Enforcement Agents}

Results revealed that from January 1, 2016 to August 31, 2017, a total of 116 youth were killed by law enforcement officers in the US. Specifically, in 2016, 63 youth were killed by police and, in 2017, 53 youth homicide by police occurred. 
(See Appendix I for more details of the frequency of youth homicide by police during these timeframes)

Age. When taking into account the age of youth victims, in 2016, data revealed a mean age of 16.8 , median of 18 , mode of 18 -years-old, and standard deviation of 3.4. Moreover, the youngest victim of police killings was 4-monthsold, with the oldest age 19. These results indicate that the average age of victims killed by police between January and December 2016 was approximately 17years-old. During this same period, 18-year-old teenagers were most likely to be killed by police and law enforcement agents in the US.

Between January and August 2017, data revealed a mean score of 16.7, median of 17, mode of 18-years-old, and standard deviation of 2.9. Furthermore, the youngest victim of police killings was 19-months-old, with the oldest age 19. These results reveal that the average age of victims killed by police and law enforcement between January and August 2017 was approximately 17-years-old. Moreover, 18-year-old teenagers were still most likely to be killed by police during this period.

Gender. When considering the gender of youth victims, between January 2016 and August 2017, a total of 108 males $(\mathrm{N}, \mathrm{M}=108)$ and 8 females $(\mathrm{N}, \mathrm{F}=8)$ were killed by police or law enforcement agents. Specifically, in 2016, 61 males and 3 females were killed, compared to 47 males and 5 females killed by police between January and August 2017. These findings reveal that in 2016, a male child or teenager was killed by police or law enforcement approximately every 72 hours (E.g. Every 3 to 4 days). Furthermore, males are more than thirteen times $(\mathrm{N}, \mathrm{M}=108)$ more likely to be killed by police than females $(\mathrm{N}, \mathrm{F}=8)$.

Race. When taking into account the racial background of youth victims, categories used in this study included Black, White, Latino, Other, and Unknown. In 2016, a total of 54 Black, 24 Latino, 24 White, 7 Other, children and teenagers were killed by police or law enforcement agents in the US. Between January and August 2017, a total of 30 Black, 14 White, 12 Latino, and 5 Other, youth homicide by police occurred. These results reveal that Black children and teenagers $(\mathrm{N}, \mathrm{MFB}=53)$ were twice as likely to be killed by the police during this period when compared to White $(\mathrm{N}, \mathrm{MFW}=24)$ and Latino $(\mathrm{N}, \mathrm{MFL}=23)$ youth.

When segregating victims according to race and gender, in 2016, a total of 29 Black, 14 White, 12 Latino, 5 Other, and O Unknown, male youth were killed by police. Between August and January 2017, a total of 24 Black, 9 Latino, and 6 White, 3 Other, and 6 Unknown male youth homicide by police occurred. These results reveal that although Black male children and teens were still most likely to be killed by police in 2016, White males were more likely than their Latino counterparts to become victims of police and law enforcement killings during this period. A disturbing finding is that between January and August 2017, Black male children and teenagers were three times more likely to be killed by police than Latino, and four times more likely than their White male counterparts.

When considering female youth victims, in 2016, a total of one Black, zero La- 
tino, and two White youth were killed by police. In 2017, three Latino, two White, and zero Black female youth homicide by police occurred. These results revealed that between January 2016 and August 2017, White female youth were four times more likely than their Black counterparts to be killed by law enforcement agents (See Appendix I and III for more details of participants' racial makeup and descriptions of Other and Unknown categories, respectively).

Location. When considering geographical location of the police killings of children and teens according to state, the eight states with the highest number of police killings of children and teenagers in 2016 included the following: California-17, Missouri-five, and Alabama, New Jersey, Texas, and Florida, along with several other states-tied at three. In 2017, results of youth killed by police according to state, yielded the following: California-10, Illinois-five, Texas-five, Colorado, and New York, Michigan, North Carolina, and Indiana, being tied at three. These results reveal that in the state of California, at least one child and teenager was killed every month in 2016 (See Appendix II for more details of state frequency of youth homicide by police during this timeframe).

\section{Outcomes}

When considering the outcomes following youth killings by police, these set of results were fairly identical. Specifically, in more than $90 \%$ of cases in this study, police or law enforcement agents were usually placed on paid administrative leave following the killing of a youth in the US. These paid administrative leave periods could last anywhere between 30 and 90 days. On the other hand, in less than $5 \%$ of cases, officers were fired from the force, and later accused of manslaughter or first-degree murder. Out of 116 cases reviewed, zero officers or law enforcement agents between the periods of 2016 to August 2017 were ever lawfully "convicted" of a crime against youth victims.

\section{Discussion}

The purpose of this manuscript was twofold: 1) To provide evidence of why Black and Brown youth fear and distrust police, and 2) To discuss implications for counselors when working with and advocating for the family and friends of youth who are killed by police. The overall focus of the manuscript was to assist counselors and service providers in understanding some of the major contributors of young people's distrust and fear toward law enforcement. The rational for this work is grounded in the reality that in the US, police kill citizenry with impunity, or death by lethal intervention (Gilbert \& Ray, 2015). These violent and traumatic events can lead to short and long-term complex grief and PTSD for survivors (Outland et al., 2020; Shane et al., 2017). Furthermore, child and teen victims of police killings have been under-researched, and there is an urgency to raise public awareness related to youthful lives that are lost at the hands of law enforcement agents (Miller, 2015; Staggers-Hakim, 2016). Raising public awareness can lead to collective efforts and actions to address and eradicate this public and social health epidemic in the US. Furthermore, counselors and service pro- 
viders may be better equipped with skills and knowledge to provide culturally sensitive care to survivors of youth killed by police.

\section{Youth Killed by Police: 72 to 120 hours}

This study discovered that a child or teen is killed by the police every five days, or every 120 hours. Specifically, results in this study revealed that in the 607-day period from January $1^{\text {st }} 2016$ to August $31^{\text {st }}, 2017$, a total of 116 children and teenagers were killed by the police. More specifically, a child or teen male was killed every 72 hours in 2016. These results stand separate from past research on police killings of adults or teens (Aymer, 2016; Chaney \& Robertson, 2013; Shane et al., 2017; Smith, 2015), in which this study placed a spotlight on "all" children and teens killed by police rather than solely Black youth. The conclusion that can be drawn here is that rather than children, in general, feeling safe and protected by law enforcement officers, these agents can be deemed as a major threat to the lives of youth, especially Black, Brown, and White males (Chaney \& Robertson, 2013; Aymer, 2016). In other words, Black, Brown and White male youth in the US remain "at-risk" of being killed by the police.

Furthermore, a disturbing result in this research was that of the 116 youth victims, it was rare or never that police officers were held accountable for their actions in the aftermath of these events (Ferner \& Wing, 2016; Gilbert \& Ray, 2015). Results in this study revealed that despite a small percentage of officers being fired from the force following police killing of a youth (5\%), zero officers were ever convicted of a crime. More importantly, most officers were granted 30 to 90 days administrative leave with pay (i.e. paid vacation). These findings align with those by Ferner and Wing (2016), in which they discovered that in 2014 2015, zero officers were convicted of killing citizens in the US. In addition, research by Gilbert and Ray (2015) further support this result, which they acknowledged that in the US, there exists a long history of extrajudicial killings by police, or death by legal intervention, primarily experienced by Black, Brown, and poor citizens. As a result, two conclusions can be drawn. First, it can be concluded that the judicial system in the US is complacent in holding police or law enforcement agents accountable for their actions following youth killings by police. Second, it can also be concluded that there is a lack of justice that is sought for youth victims in the aftermath of extrajudicial killings. Thus, the police can be deemed as the judge and jury, or the individual who identifies, intervenes, and determines the consequences for a crime, which in many cases, can lead to lethal outcomes for many Black, Brown, and White youth (Miller, 2015).

\section{Race, Gender, and Youth Killed by Police}

Black and Brown male youth, more often than not, find themselves to be victims of police killings. While navigating the complexities from childhood to adolescence, all the while trying to overcome the racially socialized terrain of the US (Chaney \& Robertson, 2013), Black and Brown male youth are confronted with another life difficulty by the powers that be who register with the force to protect them: The police. For example, the majority youth victims of police killings in this study were teen African-American and Latino males. As previously 
noted, zero officers were ever convicted for a crime for these killings. Thus, this finding is supported by the notion of structural violence discussed by Scheper-Hughes and Bourgois (2004), in which the system or structure governing the masses permit the destruction of innocent lives by those in power. As agents whose duties are to serve and protect citizens, the police can be deemed as a destructive rather than productive force in the lives of Black and Brown male youth (Aymer, 2016; Smith, 2015). Counselors and service providers have a professional mandate to protect the lives of vulnerable and marginalized youth (ACA, 2014; Lopez-Baez \& Paylo, 2009). Thus, these service providers must create a united front to stand up for Male youth of Color, and their White counterparts. This can be achieved by developing policies and political mandates that are aimed at holding police accountable for the killings of children and teens (Gilbert \& Ray, 2015; Lopez-Baez \& Paylo, 2009). Such policies should further aim to hold police to the same standards, or higher, in the court of law granted to any person or citizen of the US accused of murder. Counselors and service providers can also facilitate public forums and rallies to raise public awareness surrounding youth killings by police, with hopes that public awareness may lead to service providers and community members organizing themselves to protect our most vulnerable and marginalized youth (Counseling.org, 2019; Weitzer \& Brunson, 2009).

Finally, it is rare that White youth killed by police is a prominent topic of media discourse. Moreover, the author has yet to discover a research article that has placed attention on White youth killed by cops. Gilbert and Ray (2015) suggest that such outcomes could be due to some Whites social perception toward many Blacks as having criminal intent and perhaps deserving of their fatal encounter with police officers. In other words, Whites may collectively perceive that "only" Blacks are brutalized and killed by police, which can reduce public attention placed on the number of White youth killed by law enforcement (Smith, 2015). Thus, it is critical to acknowledge that White youth have been, and remain, victims of extrajudicial killings by police. For example, the results in this study revealed that White male youth were killed at the same rate by police as their Brown or Latino male counterparts. Moreover, from 2016 to August $31^{\text {st }}$, 2017, findings further revealed that White female children and teens were killed by police four times more frequently than their Black female counterparts.

Thus, it can be concluded that despite the lack of publicity and public discourse, White youth have also found themselves to be victims of police killings. But an important question still remains: Why are the killings of White youth by police not publicized by the media, or part of social and political discourse about this epidemic? A few reasons could be considered. First, it is rare that White youth are the topic of police killings in the media, but usually their Black and Latino counterparts (Hill, 2016). In other words, police violence is usually publicized as solely the experiences of poor youth of Color, and not White youth. Second, in most research, White youth are often painted as existing from positions of privilege and power, despite public knowledge that many White youth 
and their families reside in poor rural and urban neighborhoods. This is important to note, due to the fact that White youth who live in poor rural communities, especially those involved in illegal activities for survival, may encounter and experience the police in a similar capacity as their non-White counterparts who reside in urban settings (Miller, 2015). Finally, exposing the killings of White youth by police could lead to a public outcry to end police extrajudicial killings of all young people. Indeed, it is often the case in the US that when White youth are impacted by a societal ill (E.g. Drug epidemics), government and political officials are quick to search and find appropriate remedies to address the epidemic (Hansen \& Netherland, 2016). For example, in the article titled "Is the Prescription Opioid Epidemic a White Problem?" Hansen and Netherland (2016) suggested the following:

"In the context of public concern that White Americans are turning to heroin, policymakers are calling for reduced sentencing for nonviolent illicit drug offenses and the expansion of access to addiction treatment. At the same time, in Black and Latino communities, many drug-addicted individuals continue to be incarcerated rather than treated for their addiction" (para. 8).

Thus, public knowledge of White youth killed by police or law enforcement could lead to mass hysteria by US citizenry to end police killings of all youth.

\section{Limitations}

There are limitations in this study worth consideration. First, the database used in this study was updated on a continuous basis. Thus, some demographic information of youth victims, including race and gender, was unknown due to limited updates. Future researchers could address this concern by comparing information about victims collected from killedbypolice.net to other preexisting databases, including those from newsletters like the Guardian, $C D C$, and the Washington Post. This approach may assist future researchers to ensure that all demographic information about youth victims are accurate and up-to-date.

Second, this study used descriptive statistics to understand the outcomes and police accountability following a youth homicide by police. This notion is a limitation on the grounds that most information related to police killings is inaccessible to the public, primarily when the case is turned over to the state or federal bureau of investigations, which is a section of the police department (Shane et al., 2017). In other words, the police department is usually responsible for investigating their own officers following a youth killing by police. As a result, future researchers can address the above-mentioned limitation by collecting the narratives of the family and friends of youth victims of police homicide. These narratives are important to consider due to the fact that these individuals are usually the most impacted by the traumatic death of a youth killed by police. Thus, the experiences of family, friends, and community members of deceased youth can provide vital information regarding 1) police accountability following these situations, and 2) the impact of youth killings by police on survivors' overall well-being (Kristensen, Weisaeth, \& Heir, 2012; Nakajima et al., 2012; Zinzow et al., 2009). Using qualitative approaches, such as in-depth interviews and focus 
groups, information collected from such an investigation could provide vital knowledge for counselors and service providers who find themselves in a position to provide crisis support and advocacy for the family and friends of the deceased youth (Outland et al., 2020).

\section{Conclusion and Recommendations}

In conclusion, we are living in strange times when government agents who are hired to protect Black and Brown youth become a direct threat to their existence. Moreover, it is a complete tragedy when these agents of the law, are rarely, if ever, convicted of a crime for killing our young people. However, as tragic as this situation remains, it is a faulty conclusion to place complete ownership of youth killings by police in the US on the backs of these officers. With a closer examination, it seems clear that citizens of the US are dealing with a judicial and government system that turns a blind eye to the actions and behaviors of the police (Hill, 2016). In addition, some US citizens are complicit toward police killings of youth due to the lack of public outcry to end this epidemic (Chaney \& Robertson, 2013). In other words, the judicial and government branch, as well as US citizenry, have yet to consider and treat police killing of youth, especially Black and Brown teen males, as a public health epidemic in the US that is worthy of government intervention. Thus, in order for youth killings by police to come to an end, several strategies must be considered.

First, community members, especially in poor urban and rural areas, must begin to organize themselves to protect youth from the police. Counselors and service providers, as a result of having connections to multiple stakeholders in the community, can play a vital role in organizing community members. This could be accomplished by residents starting neighborhood watch units focusing on monitoring the actions and behaviors of police officers on duty. These units must be organized and educated regarding laws related to police accountability, responsibility, and service to citizens, as well as, citizens' legal rights during police encounters (Miller, 2015, Belur, 2010; Weitzer \& Brunson, 2009; Muntaqim, 2010).

Furthermore, government officials must consider extrajudicial killings of citizens by police, especially youth, as a state and national epidemic. Because this epidemic will not fix itself, there is a need for government, and perhaps military, intervention. Counselors and service providers can act as change agents in leading the charge to encourage government officials, and concerned community members, to work collectively to develop new laws and policies that protect youth from police violence (Weitzer \& Brunson, 2009). This could be done by creating a bill or law to hold police accountable for their actions during and following youth killings by police. Such a bill or law may require officers to face a jury trial of their peers and neighbors in court. In this case, jurors could consist of a combination of citizens from the communities of the deceased youth victim and the accused officer (Gilbert \& Ray, 2015). Combining citizens from different communities may address potential juror biases related to past experiences of 
the officer on duty, or as a neighbor. The purpose of a jury trial would be to present "all" the evidence of a case involving a youth homicide by police to a non-biased jury, with hopes that these common residents could determine the innocence or guilt of the officer. These trials could contribute to a form of justice granted by the courts to the family members, friends, and loved ones of the deceased youth.

In addition, youth advocates, family and community members of victims, along with trusted activists must collectivize efforts to demand justice and police accountability (Lopez-Baez \& Paylo, 2009). Specifically, in the 1960s and 70s, historical civil rights and Black Power movements, including the Student Nonviolent Coordinating Committee (SNCC) and the Black Panther Party (BPP), evolved to confront and eradicate police killings of Black and Brown people. These movements fueled activism in the 1980s by organizations such as the M.O.V.E., which also shed light and heightened contradictions surrounding corporate capitalism, police brutality and killings in West Philadelphia (Abu-Jamal, 2016). Despite calculated neutralization of Civil Rights and Black Power movements by the US government's Counter Intelligence Program (CointelPro) (Muntaqim, 2010) and the bombing and shoot-in of the M.O.V.E. house by Philadelphia police in 1985, these movements influenced the foundation for current day activism against police terrorism (Abu-Jamal, 2015). Specifically, the Movement for Black Lives, or Black Lives Matter (BLM), has established a firm international and national coalition of diverse activists and common folks against police killings in the US and beyond. Thus, collective action carries the capacity to not only provide safety and protection for potential youth victims of police killings, but can also act as the base in which justice, dignity, and equity for deceased youth are demanded (Hill, 2016). In recent times, systemic and policy changes have resulted from the above-mentioned activism, which have included monetary compensation to victims' family, law reforms, increased police transparency while on duty (e.g. body cameras), and police accountability.

Finally, youth survivors are in need of continue support, compassion, and care from trusted adults. Specifically, these youth survivors can include the siblings, friends, classmates, teammates, or associates of youth victims of police killings. Trusted adults must stay mindful that youth process and deal with grief differently than adults, which physical expressions, rather than talking, are likely responses during their grieving process (Zinzow et al, 2009). Thus, youth survivors must be granted space, time, and opportunity to process and express their feelings and thoughts surrounding the death of a peer (Kristensen et al., 2012). Individual and group counseling, community engagement and activism, and or peer support groups in school and the community, can be useful tools of support, care, and nurturing for youth survivors.

\section{Conflicts of Interest}

The author declares no conflicts of interest regarding the publication of this paper. 


\section{References}

Abu-Jamal, M. (2015). Writing on the Wall: Selected Prison Writings of Mumia AbuJamal. New York: City Light Books.

Abu-Jamal, M. (2016). We Want Freedom: A Life in the Black Panther Party. Brooklyn, NY: Common Notions.

American Counseling Association (ACA) (2014). ACA Code of Ethics. https://www.counseling.org/docs/default-source/default-document-library/2014-codeof-ethics-finaladdress.pdf

Aymer, S. (2016). "I Can't Breathe": A Case Study-Helping Black Men Cope with RaceRelated Trauma Stemming from Police Killing and Brutality. Journal of Human Behavior in the Social Environment, 26, 367-376.

https://doi.org/10.1080/10911359.2015.1132828

Belur, J. (2010). Permission to Shoot. Police Use of Deadly Force in Democracies. New York: Springer. https://doi.org/10.1007/978-1-4419-0975-6

Chaney, C. V., \& Robertson, R. (2013). Racism and Police Brutality in America. Journal of African American Studies, 17, 480-505. https://doi.org/10.1007/s12111-013-9246-5

Cohen, R. (2017). US Government Undercounted Civilians Killed by Police. https://www.reuters.com/article/us-health-officialcounts-police-killings/u-s-governme nt-undercounted-civilians-killed-by-police-idUSKBN1CG2FT

Counseling.org American Counseling Association (ACA) Website (2019). Liberty and Justice for All Statement.

https://www.counseling.org/social-justice/liberty-and-justice-for-all

Craven, J. (2017). More than 250 Black People Were Killed by Police in 2016 [Updated]. Huffington Post.

https://www.huffingtonpost.com/entry/black-people-killed-by-police-america us 577 da633e4b0c590f7e7fb17

Ferner, M., \& Wing, N. (2016). Here's How Many Cops Got Convicted of Murder Last Year for On-Duty Shootings.

https://www.huffingtonpost.com/entry/police-shooting-convictions us 5695968ce4b0 $\underline{86 \mathrm{bc} 1 \mathrm{~cd} 5 \mathrm{~d} 0 \mathrm{da}}$

Gilbert, K. L., \& Ray, R. (2015). Why Police Kill Black Males with Impunity: Applying Public Health Critical Race Praxis (PHCRP) to Address the Determinants of Policing Behaviors and "Justifiable" Homicides in the US. Journal of Urban Health: Bulletin of the New York Academy of Medicine, 93, 122-140.

https://doi.org/10.1007/s11524-015-0005-X

Hansen, H., \& Netherland, J. (2016). Is the Prescription Opioid Epidemic a White Problem? American Journal of Public Health, 106, 2127-2129. https://doi.org/10.2105/AJPH.2016.303483

Hill, M. L. (2016). Nobody: Causalities of America's War on the Vulnerable, from Ferguson to Flint and beyond. New York: Atria Books.

Johnson, K., Hoyer, M., \& Heath, B. (2014). Local Police Involved in 400 Killings per Year. US Today News.

http://www.UStoday.com/story/news/nation/2014/08/14/police-killings-data/14060357

Killedbypolice (2016). https://killedbypolice.net/

Killedbypolice (2021). https://killedbypolice.net/

Kristensen, P., Weisaeth, L., \& Heir, T. (2012). Bereavement and Mental Health after Sudden and Violent Losses: A Review. Psychiatry, 75, 76-97.

https://doi.org/10.1521/psyc.2012.75.1.76 
Lopez-Baez, S. I., \& Paylo, M. J. (2009). Social Justice Advocacy: Community Collaboration and Systems Advocacy. Journal of Counseling and Development, 87, 276-283. https://doi.org/10.1002/j.1556-6678.2009.tb00107.x

Miller, L. (2015). Why Cops Kill: The Psychology of Police Deadly Force Encounters. Aggression and Violent Behavior, 22, 97-111. https://doi.org/10.1016/j.avb.2015.04.007

Muntaqim, J. (2010). We Are Our Own Liberators. Selected Prison Writings. Portland, OR: Arissa Media Group.

Nakajima, S., Ito, M., Shirai, A., \& Konishi, T. (2012). Complicated Grief in Those Bereaved by Violent Death: The Effects of Post-Traumatic Stress Disorder on Complicated Grief. Dialogues in Clinical Neuroscience, 14, 210-214.

https://doi.org/10.31887/DCNS.2012.14.2/snakajima

Outland, R., Noel T., Rounsville, K., Boatwright, T., Waleed, C., \& Abraham, A. (2020). Living with Trauma: Impact of Police Killings on the Lives of the Family and Community of Child and Teen Victims. Current Psychology. https://doi.org/10.1007/s12144-020-01129-w

Rheingold, A. A., Zinzow, H., Hawkins, A., Saunders, B. E., \& Kilpatrick, D. G. (2012). Prevalence and Mental Health Outcomes of Homicide Survivors in a Representative US Sample of Adolescents: Data from the 2005 National Survey of Adolescents. Journal of Child Psychology and Psychiatry, 53, 687-694. https://doi.org/10.1111/j.1469-7610.2011.02491.x

Scheper-Hughes, N., \& Bourgois, P. (2004). Introduction: Making Sense of Violence. In N. Scheper-Hughes, \& P. Bourgois (Eds.), Violence in War and Peace: An Anthology (pp. 1-32). Malden, MA: Blackwell Publishing.

Shane, J. M., Lawton, B., \& Swenson, Z. (2017). The Prevalence of Fatal Police Shootings by U.S. Police, 2015-2016: Patterns and Answers from a New Data Set. Journal of Criminal Justice, 52, 101-111. https://doi.org/10.1016/j.jcrimjus.2017.05.001

Smith, J. R. (2015). Unequal Burdens of Loss: Examining the Frequency and Timing of Homicide Deaths Experienced by Young Black Men across the Life Course. American Journal of Public Health, 3, 483-489. https://doi.org/10.2105/AJPH.2014.302535

Staggers-Hakim, R. (2016). The Nation's Unprotected Children and the Ghost of Mike Brown, or the Impact of National Police Killings on the Health and Social Development of African American Boys. Journal of Human Behavior in the Social Environment, 26, 390-399. https://doi.org/10.1080/10911359.2015.1132864

Strohlic, N. (2014). The 14 Black Teens Killed by Cops since Michael Brown. https://www.thedailybeast.com/the-14-teens-killed-by-cops-since-michael-brown

US Legal (2017). Definition of Extrajudicial Killing. https://definitions.uslegal.com/e/extrajudicial-killing

Weitzer, R., \& Brunson, R. K. (2009). Strategic Responses to the Police among Inner-City Youth. Sociological Quarterly, 50, 235-256. https://doi.org/10.1111/j.1533-8525.2009.01139.x

Zinzow, H. M., Rheingold, A. A., Hawkins, A. O., Saunders, B. E., \& Kilpatrick, D. G. (2009). Losing a Loved One to Homicide: Prevalence and Mental Health Correlates in a National Sample of Young Adults. Journal of Traumatic Stress, 22, 20-27. https://doi.org/10.1002/jts.20377 


\section{Appendix I: Charts and Graphs}

Children and Teenagers Killed by Police and Law Enforcement Officers in the US, 2016-August $31^{\text {st }}$, 2017 (Gender)

\begin{tabular}{lll}
\hline & Total \# of Victims & Total \# of Males \\
\hline Jan. $1^{\text {st }}, 2016$ to Aug. $31^{\text {st }}, 2017$ & $(\mathrm{~N})=116$ & $(\mathrm{~N}, \mathrm{M})=108$ \\
Jan. $1^{\text {st }}, 2016$ to Dec. $1^{\text {st }}, 2016$ & $(\mathrm{~N}(2016))=63$ & $(\mathrm{~N}, \mathrm{M}(2016))=61$ \\
Jan. $1^{\text {st }}, 2017$ to Aug. $31^{\text {st }}, 2017$ & $(\mathrm{~N}(2017))=53$ & $(\mathrm{~N}, \mathrm{M}(2017))=47$ \\
\hline
\end{tabular}

Children and Teenagers Killed by Police and Law Enforcement Officers in the US, 2016-August $31^{\text {st }}, 2017$ (Males, Race)

\begin{tabular}{ccccc}
\hline & $\begin{array}{c}\text { Total \# of } \\
\text { White Males }\end{array}$ & $\begin{array}{c}\text { Total \# of } \\
\text { Black Males }\end{array}$ & $\begin{array}{c}\text { Total \# of } \\
\text { Latino Males }\end{array}$ & $\begin{array}{c}\text { Total \# of } \\
\text { Other Males }\end{array}$ \\
\hline Jan. $1^{\text {st }}, 2016$ to Aug. $31^{\text {st }}, 2017$ & $(\mathrm{~N}, \mathrm{MW})=20$ & $(\mathrm{~N}, \mathrm{MB})=53$ & $(\mathrm{~N}, \mathrm{ML})=21$ & $(\mathrm{~N}, \mathrm{MO})=7$ \\
Jan. $1^{\text {st }}, 2016$ to Dec. $1^{\text {st }}, 2016$ & $(\mathrm{~N}, \mathrm{MW}(2016))=14$ & $(\mathrm{~N}, \mathrm{MB}(2017))=29$ & $(\mathrm{~N}, \mathrm{ML}(2016))=12$ & $(\mathrm{~N}, \mathrm{MO}(2016))=5 \quad(\mathrm{~N}, \mathrm{MU}(2016))=0$ \\
Jan. $1^{\text {st }}, 2017$ to Aug. $31^{\text {st }}, 2017$ & $(\mathrm{~N}, \mathrm{MW}(2017))=6$ & $(\mathrm{~N}, \mathrm{MB}(2017))=24$ & $(\mathrm{~N}, \mathrm{ML}(2017))=9$ & $(\mathrm{~N}, \mathrm{MO}(2017))=3 \quad(\mathrm{~N}, \mathrm{MU}(2017))=6$ \\
\hline
\end{tabular}

Children and Teenagers Killed by Police and Law Enforcement Officers in the US, 2016-August $31^{\text {st }}, 2017$ (Females, Race)

\begin{tabular}{|c|c|c|c|c|c|}
\hline & $\begin{array}{l}\text { Total \# of } \\
\text { White Females }\end{array}$ & $\begin{array}{l}\text { Total \# of } \\
\text { Black Females }\end{array}$ & $\begin{array}{l}\text { Total \# of } \\
\text { Latino Females }\end{array}$ & $\begin{array}{l}\text { Total \# of } \\
\text { Other Females }\end{array}$ & $\begin{array}{l}\text { Total \# of } \\
\text { Unknown Females }\end{array}$ \\
\hline Jan. $1^{\text {st }}, 2016$ to Aug. $31^{\text {st }}, 2017$ & $(\mathrm{~N}, \mathrm{FW})=4$ & $(\mathrm{~N}, \mathrm{FB})=1$ & $(\mathrm{~N}, \mathrm{FL})=3$ & $(\mathrm{~N}, \mathrm{FO})=0$ & $(\mathrm{~N}, \mathrm{FU})=0$ \\
\hline Jan. $1^{\text {st }}, 2016$ to Dec. $1^{\text {st }}, 2016$ & $(\mathrm{~N}, \mathrm{FW}(2016))=2$ & $(\mathrm{~N}, \mathrm{FB}(2016))=1$ & $(\mathrm{~N}, \mathrm{FL}(2016))=0$ & $(\mathrm{~N}, \mathrm{FO}(2016))=0$ & $(\mathrm{~N}, \mathrm{FU}(2016))=0$ \\
\hline Jan. $1^{\text {st }}, 2017$ to Aug. $31^{\text {st }}, 2017$ & $(\mathrm{~N}, \mathrm{FW}(2017))=2$ & $(\mathrm{~N}, \mathrm{FB}(2017))=0$ & $(\mathrm{~N}, \mathrm{FL}(2017))=3$ & $(\mathrm{~N}, \mathrm{FO}(2017))=0$ & $(\mathrm{~N}, \mathrm{FU}(2017))=0$ \\
\hline
\end{tabular}

Children and Teenagers Killed by Police and Law Enforcement Officers in the US, 2016-August $31^{\text {st }}, 2017$ (Males/Females Combined, Race)

\begin{tabular}{|c|c|c|c|c|c|}
\hline & $\begin{array}{l}\text { Total \# of White } \\
\text { Males/Females }\end{array}$ & $\begin{array}{l}\text { Total \# of Black } \\
\text { Males/Females }\end{array}$ & $\begin{array}{c}\text { Total \# of Latino } \\
\text { Males/Females }\end{array}$ & $\begin{array}{l}\text { Total \# of Other } \\
\text { Males/Females }\end{array}$ & $\begin{array}{c}\text { Total \# of Unknown } \\
\text { Males/Females }\end{array}$ \\
\hline Jan. $1^{\text {st }}, 2016$ to Aug. $31^{\text {st }}, 2017$ & $(\mathrm{~N}, \mathrm{MFW})=24$ & $(\mathrm{~N}, \mathrm{MFB})=54$ & $(\mathrm{~N}, \mathrm{MFL})=24$ & $(\mathrm{~N}, \mathrm{MFO})=7$ & $(\mathrm{~N}, \mathrm{MFU})=0$ \\
\hline Jan. $1^{\text {st }}, 2016$ to Dec. $1^{\text {st }}, 2016$ & $(\mathrm{~N}, \mathrm{MFW}(2016))=14$ & $(\mathrm{~N}, \mathrm{MFB}(2016))=30$ & $(\mathrm{~N}, \mathrm{MFL}(2016))=12$ & $(\mathrm{~N}, \mathrm{MFO}(2016))=5$ & $(\mathrm{~N}, \mathrm{MFU}(2016))=0$ \\
\hline Jan. $1^{\text {st }}, 2017$ to Aug. $31^{\text {st }}, 2017$ & $(\mathrm{~N}, \mathrm{MFW}(2017))=8$ & $(\mathrm{~N}, \mathrm{MFB}(2017))=24$ & $(\mathrm{~N}, \mathrm{MFL}(2017))=12$ & $(\mathrm{~N}, \mathrm{MFO}(2017))=3$ & $(\mathrm{~N}, \mathrm{MFU}(2017))=0$ \\
\hline
\end{tabular}

\section{Appendix II: State Frequency}

\section{State Frequency: \\ 2016:}

Alabama: 3

Arkansas: 1

Arizona: 3

California: 17

Florida: 3

Illinois: 3

Kansas: 1

Kentucky: 1

Louisiana: 1 
Maryland: 3

Michigan: 1

Missouri: 5

Mississippi: 1

North Carolina: 2

New Jersey: 3

New Mexico: 1

New York: 2

Ohio: 2

Oregon: 1

Pennsylvania: 2

South Dakota: 1

Texas: 3

Virginia: 1

Washington: 1

Wisconsin: 1

Lan. to Aug. 2017:

Arkansas:

California: 10

Illinois: 5

Alabama: 2

Arkansas: 1

Arizona: 1

Colorado: 3

Connecticut: 1

Georgia: 1

Indiana: 3

Louisiana: 1

Maryland: 1

Maine: 1

Michigan: 3

North Carolina: 3

New Mexico: 1

New York: 3

Ohio: 1

Oklahoma: 2

Oregon: 1

Texas: 5

Utah: 1

Washington: 1

Wisconsin: 1 


\section{Appendix III: Participant Demographics, Other and Unknown}

\section{Notes:}

- * - Males/Other (FB) category was created for teenage males killed by police to identify victims with a different racial background than White, Latino, and Black. According to the database, this category could include Indigenous, Alaskan, Asian, Middle Eastern, and Pacific Islander.

- **-Males/Unknown (MU) category was created for teenage males killed by police to identify victims whose racial background is "unknown."

- *** - Females/Other (FB) category was created for teenage females killed by police to identify victims with a different racial background than White, Latino, and Black. According to the database, this category could include Indigenous, Alaskan, Asian, Middle Eastern, and Pacific Islander. 